\title{
The Zeyi Cave Geosite in Northern Ethiopia
}

\section{Jan Nyssen $^{1}$ (D) $\cdot$ Meheretu Yonas ${ }^{2} \cdot$ Sofie Annys ${ }^{1} \cdot$ Tesfaalem Ghebreyohannes $^{3}$ - Wolbert Smidt ${ }^{4,5}$. Kiros Welegerima ${ }^{2} \cdot$ Seifu Gebreselassie ${ }^{6} \cdot$ Andrea Sembroni $^{7} \cdot$ Francesco Dramis $^{7} \cdot$ Camille Ek $^{8} \cdot$ David Causer $^{9}$}

Received: 30 March 2019 / Accepted: 8 January 2020

(C) The European Association for Conservation of the Geological Heritage 2020

\begin{abstract}
Despite the high geoheritage value of caves and karsts, northern Ethiopia's largest cave at Zeyi $\left(13.5586^{\circ} \mathrm{N}, 39.1454^{\circ} \mathrm{E}\right)$ in the Dogu'a Tembien district has received little attention so far. We have studied its geological, geomorphic, socio-cultural and historical dimensions in a holistic way. The basal member of the Antalo Limestone, in which the Zeyi cave is located, consists of grainstone and wackestone with subordinate marly interlayers. Over a length of $364 \mathrm{~m}$, the oval-shaped gallery displays stalagmites, stalactites, five columns, dissolution holes ("bell-holes") following joints, stalagmitic floors and other concretions or speleothems. In the absence of any dating of the cave, we contrasted its elevation above the current local base level with known average incision rates of the northern Ethiopian highlands to reconstruct its age, which was calculated as at least 2 to 4 million years. The palaeo-environmental information that is archived in the Zeyi cave sediment would hence cover the Pleistocene. The graves in the sediment at the bottom of the Zeyi cave further indicate that the place could be an ancient burial site, which gives scope for archaeological research. Zeyi boosts a unique combination of abiotic, biotic and cultural components: the nineteenth $\mathrm{c}$. church under the overhanging cliff; the unique cave; the speleothems, cliffs and gorges; and the cave's bat colony which has been genetically confirmed to be composed of three syntopically roosting species. Accounting for a good balance between cave research, community-based geotourism, geoconservation and biodiversity conservation, the Zeyi cave has strong credentials to become a top geotouristic site in northern Ethiopia. However, major work needs to be done, including granting access for women and organising community-based geotourism.
\end{abstract}

Keywords Cave $\cdot$ Geotourism $\cdot$ Antalo Limestone $\cdot$ Karst $\cdot$ Bats $\cdot$ Palaeo-environment

Electronic supplementary material The online version of this article (https://doi.org/10.1007/s12371-020-00446-7) contains supplementary material, which is available to authorized users.

Jan Nyssen

jan.nyssen@ugent.be

1 Department of Geography, Ghent University, Ghent, Belgium

2 Department of Biology and Institute of Mountain Research \& Development, Mekelle University, Mekelle, Ethiopia

3 Department of Geography and Environmental Studies, Mekelle University, Mekelle, Ethiopia

4 Research Centre Gotha of Erfurt University, Gotha, Germany

5 Department of History and Heritage Management, Mekelle University, Mekelle, Ethiopia

6 EthioTrees Project, Hagere Selam, Dogu'a Tembien, Ethiopia

7 Department of Geology, Roma Tre University, Rome, Italy

8 Institute of Geography, Liège University, Liège, Belgium

9 The Old Gaol, Rock St. Croscombe, Wells, Somerset BA5 3QT, UK

\section{Introduction}

Given the semi-closed environment, and its often spectacular setting, caves are most probably the first geosites that humans have valued and respected. As in earlier cave studies (Hamilton-Smith 2007; Pierson 2009; Spate and Baker 2018; Watson et al. 1997), the karst values of northern Ethiopia's largest cave at Zeyi are approached in a holistic way, involving abiotic, biotic, socio-cultural and historical dimensions.

While most rock churches in the Tigray region were hewn in sandstone of different ages (Asrat 2002), the Abune Aregawi church at Zeyi $\left(13.5586^{\circ} \mathrm{N}, 39.1454^{\circ} \mathrm{E}\right)$ in the Dogu'a Tembien district is built at the entrance of a natural limestone cave in the Antalo Limestone, a marly-carbonatic marine succession of Jurassic age (Bosellini et al. 1997). The wider surroundings of Mekelle, the capital city of Tigray, are indeed characterised by the occurrence of various karst landforms including caves, speleothems and lapiez (Catlin et al. 1973) and a large number of Quaternary tufa dams (Berakhi 
et al. 1998; Dramis and Fubelli 2019; Moeyersons et al. 2006).

At Zeyi, after a climb through the buildings of the church that has been constructed under an overhanging cliff of limestone (Fig. 1), one can access the largest cave of Tigray, and seventh longest of Ethiopia (Asrat 2015). Over a length of $364 \mathrm{~m}$, the ca. 20-m wide, oval-shaped gallery displays stalagmites, stalactites, five approx. 10-m-high columns, dissolution holes ("bell-holes") following joints, and stalagmitic floors, as well as speleothems, some of which cover an ancient jar placed to collect droplets from the cave ceiling that are used by the priests as "holy water". The cave, that is also home to hundreds if not thousands of bats, is between 3 - and $15-\mathrm{m}$ high, to which several metres of sediment that fill its lower part should be added.

The objectives of this study are (i) to present the geological, geomorphological, biotic and cultural setting of the Zeyi cave, (ii) to indicate its unique potential for archaeological and palaeo-environmental research in north Ethiopia and (iii) to evaluate the scope for geotourism to the cave sites of the Dogu'a Tembien district.

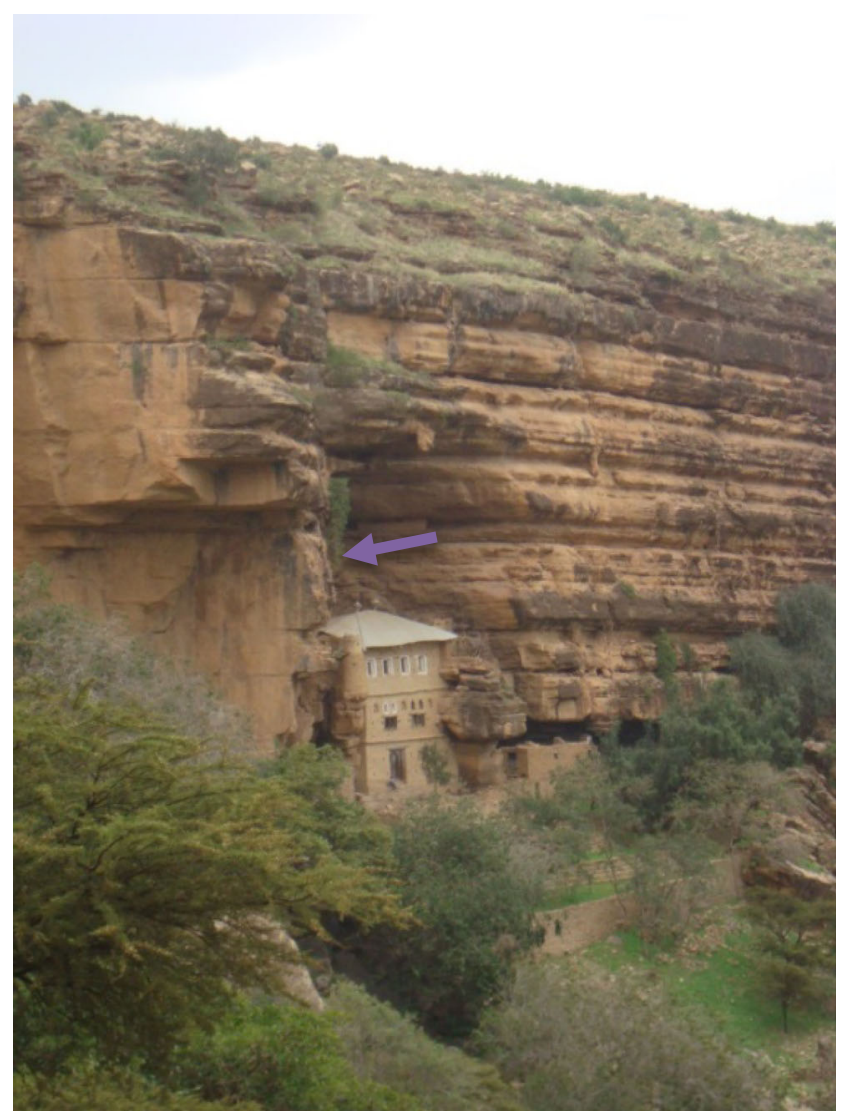

Fig. 1 The basal member of the Antalo limestone near Zeyi village. The Abune Aregawi church is built under the overhanging cliff that hosts a 364-m long cave in the limestone. Cave entrance is indicated by an arrow. Photo Jan Nyssen (2013). (Dramis and Fubelli 2019)
Fig. 2 Regional geological map, with location of caves and other places mentioned in the article. Two geological sections allow to envisage the configuration of the geological context in which the karst systems developed. Lithology, stratigraphy and geometry of the main faults are in line with geological maps and literature (Arkin et al. 1971; Beyth 1972; Bosellini et al. 1997; Russo et al. 1999; Sembroni et al. 2016; Sembroni et al. 2019; Sembroni et al. 2017; Gebreyohannes et al. 2010; Chernet and Eshete 1982)

\section{Geological and Geomorphological Setting}

The Antalo Limestone (Fig. 2) is a shallow-water succession made of sub-horizontal alternating layers of limestone, marl shale (Upper Oxfordian-Kimmeridgian; ca. 160-150 Ma), overlying the continental Adigrat Sandstone (Trias). It was deposited by marine ingression over a low angle $\left(1-2^{\circ}\right)$, southeast-dipping continental ramp (Bosellini et al. 1997). The upper transition to the Amba Aradam Formation, made of sandstone with conglomerate levels, is the result of an uplift-induced regression to a continental environment and is marked by a gentle angular unconformity (Bosellini et al. 1997). The Antalo Limestone largely outcrops in the Mekelle Outlier and is also found elsewhere in Ethiopia such as in the Blue Nile gorge, in the Harar Plateau and around Dire Dawa, where it hosts most of Ethiopia's caves (Asrat 2015).

The Antalo Limestone Formation is made of four depositional members: (1) a basal member, in which the Zeyi cave is located, made of grainstone and wackestone, with subordinate marly interlayers and a coral stromatoporoid level in the upper part (Fig. 1); (2) an arenaceous limestone member deposited in an estuarine or lagoonal environment (Fig. S1 in the Online Supplement); (3) a relatively deep-water member made up of micritic limestone with intercalation of wackestone and coquina beds and (4) a marly-limestone top member, whose basal part is made of cherty limestone (Fig. S2) (Bosellini et al. 1997; Dramis and Fubelli 2019). The thickness of the Antalo Limestone reaches up to $700 \mathrm{~m}$. The layering is sub-horizontal, similar to the underlying sedimentary formations (Bosellini et al. 1997; Dramis and Fubelli 2019).

The Antalo Limestone is locally covered by Amba Aradam sandstone and basalts; it overlies the Adigrat sandstone and the Precambrian basement (Sembroni et al. 2019). The sandstone formations, and particularly the Adigrat sandstone, are cliff-forming (Bussert and Nyssen 2019). Under it, the exhumed planation surface at the top of the Precambrian metamorphic rocks (Coltorti et al. 2007) offers stronger resistance against erosion, what makes that the regressive erosion could not fully dissect it; rivers typically incised deep gorges in the sedimentary rocks, then run for $10-20 \mathrm{~km}$ on top of the exhumed planation surface, after which they plunge again in deep gorges in the Precambrian rock (Sembroni et al. 2017). 

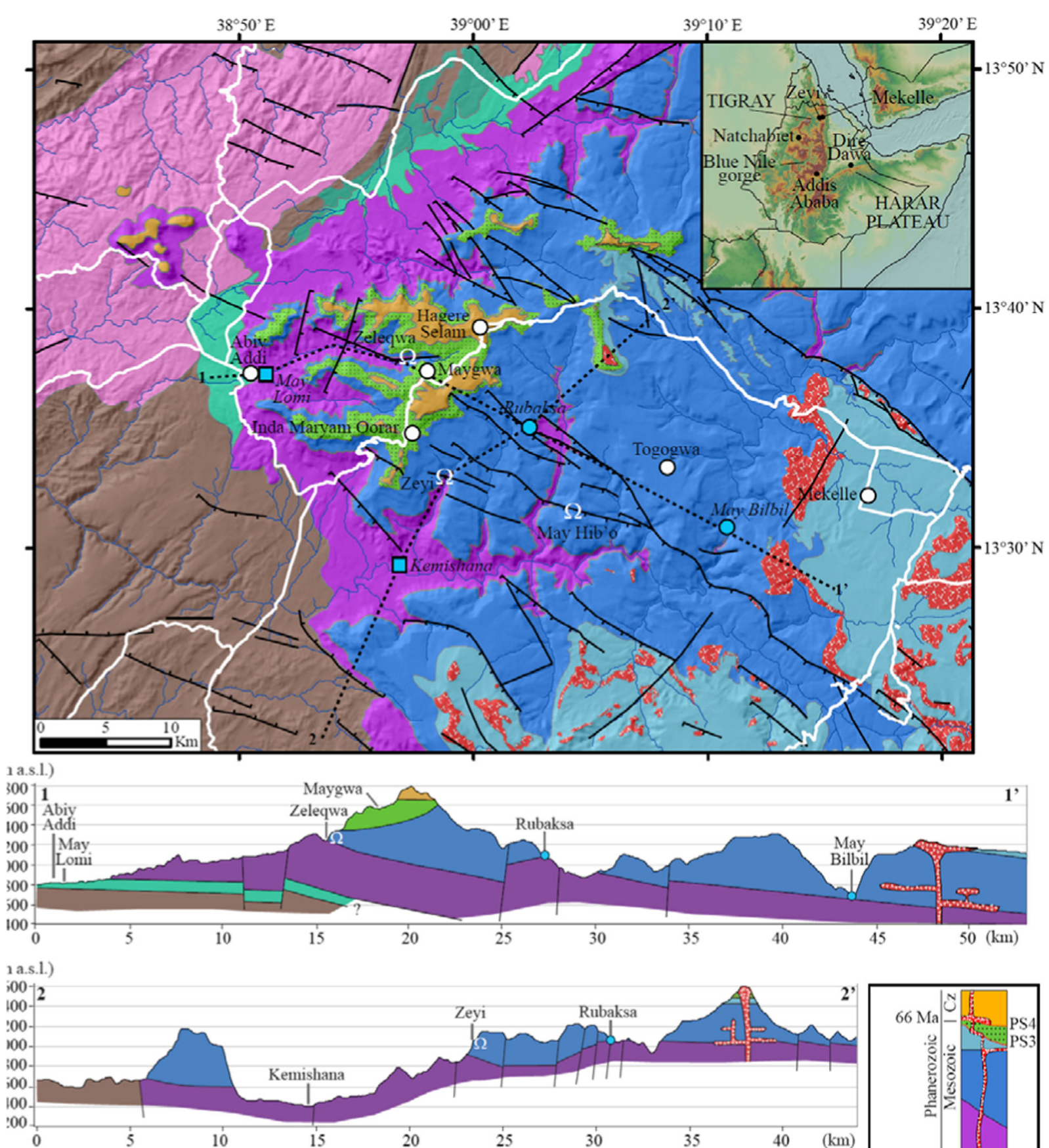

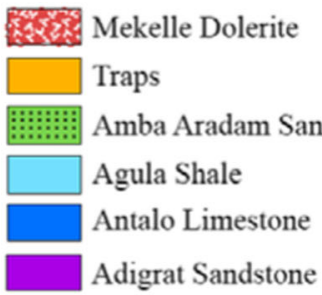

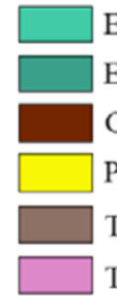

Edaga Arbi Glacial

Enticho Sandstone

Granitoids (unknown relation)

Pre- to Syn-Tectonic Granite

Tambien Group

Tsaliet Group

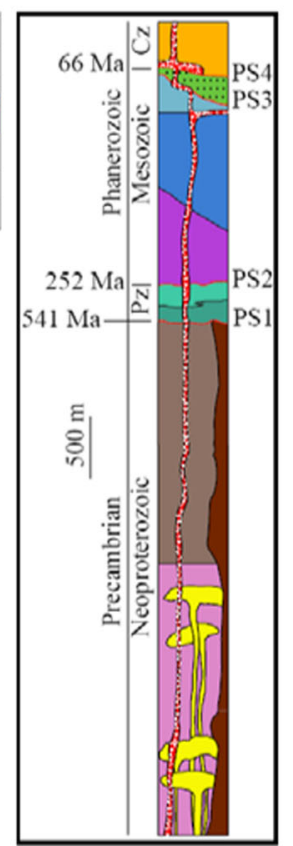




\section{Field Observations}

On 24 February 2017, 26 November 2017 and 27 April 2019, the authors were the first scientists to document the cave since Causer (1962). In 1972, the British Cave Research Group was not granted access (Catlin et al. 1973). The recent visits allowed planimetric measurements and re-drawing of the cave map produced by Causer (1962) (Fig. 3).

Even without visiting the cave, the view on the surrounding landscapes (Fig. 4; Fig. S3) and the monumental church under

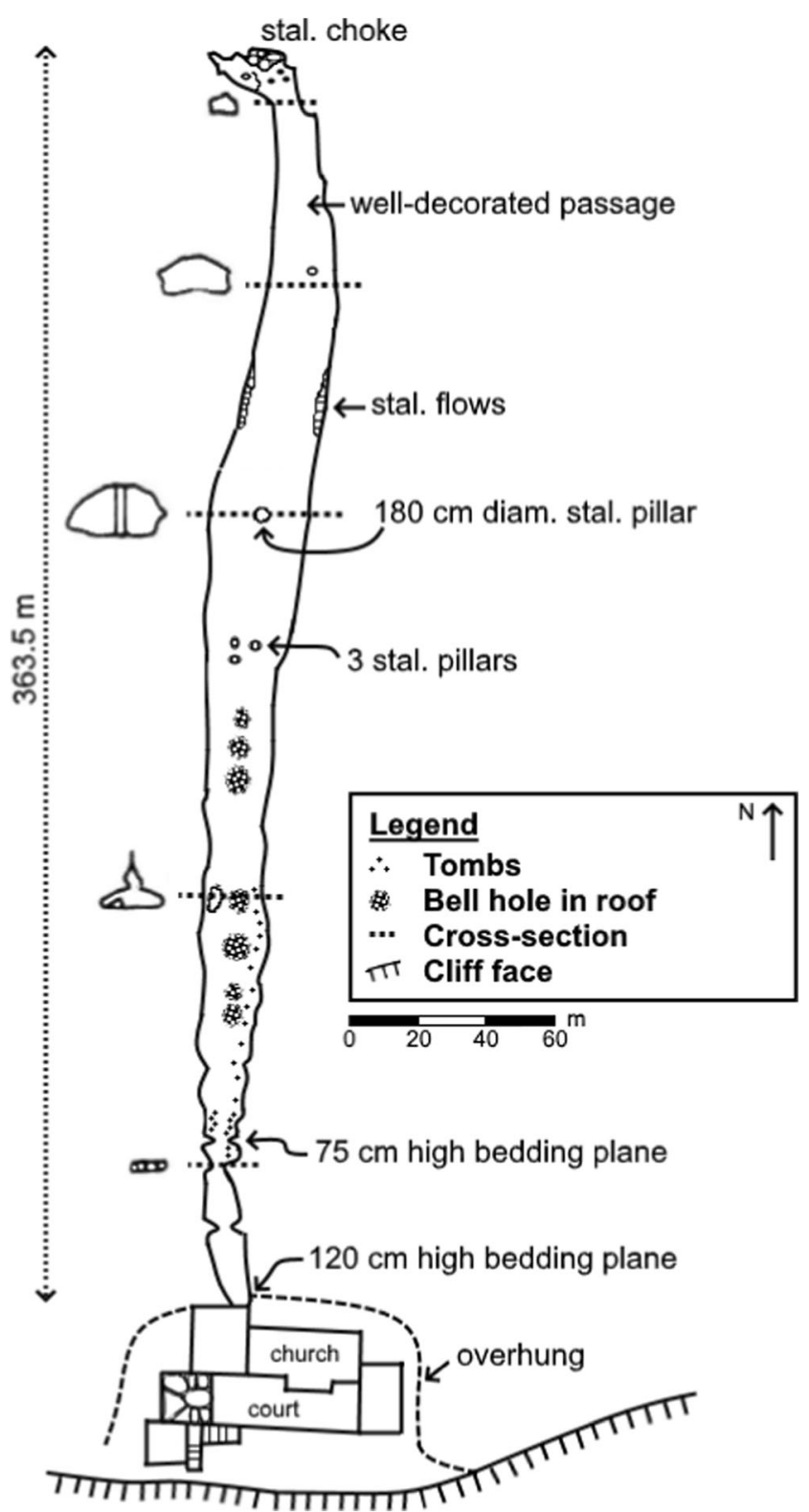

Fig. 3 Ground plan of Zeyi cave in Tigray, Ethiopia. Cliff overhang and church buildings sketched in only. Original drawing by D.J. Causer and D.A. Wheeler (Causer 1962). Redrawn by Sofie Annys with ground measurement data (Seifu Gebreslassie, Jeroen Berlo) and inputs from the authors. Five cross-sections are schematically represented at left of the gallery the overhanging limestone cliff (Fig. 1; Fig. S4) were worth the trek of $6 \mathrm{~km}$ and 560 elevation metres between Inda Maryam Qorar and Zeyi (Table S1; Nyssen 2019). Negotiations were necessary before entering the cave, as it is located behind the Abune Aregawi church, and de facto its property. The cave is said to have been discovered in the midnineteenth c. by monk Geta Hailu behind thorny redwing lianas (Pterolobium stellatum) that then covered the cliff face. Informed about the existence of the cave, the Ethiopian emperor Yohannes IV mobilised 300 people from Dogu'a Tembien to build a church near the cave entrance. Plant and Buxton (1970) studied these church buildings (Fig. S4, left) and mention "the entire series of buildings mounted one above the other with terraces and boweries built on rock promontories. High up under the cave roof is the simple square church (...). Under the roof, a series of cell-like graves; below and to one side the bakery; to the other, the living quarters, built on a jutting out piece of solid rock. The concept of levels interweaving, set back one upon another, connected by rude newel stairs, $(\ldots)$ is to be seen nowhere else in Tigray. One painting on a wall with a snake". A spiral staircase (Fig. 5) leads to a small room with a doorway of approx. $50 \mathrm{~cm} \times 50 \mathrm{~cm}$ at the back (Fig. 6), giving access to the cave. Yohannes' descendants continued nurturing this church; for instance, his grandson and last governor of Tigray in feudal times, Mengesha Seyoum, financially supported the Zeyi church and monastery and organised the visit of the cave by co-author Causer in 1962. A new church has been built besides the old church buildings, in traditional monumental Tigrayan style (Fig. S4, right).

When entering the cave, which is at the level of the roof of the new church, one first crawls through a narrow passage near the entrance (0.7-m high) (Fig. 7). The low height is due to the bottom of the cave being filled with a thick pack of sediment, in which a further passage has been excavated (Fig. 8). There are partly damaged stalactite curtains on both sides (Fig. 9). Damage is not mentioned by Causer (1962); hence, the curtains would still have been intact in 1962. The cave is a south-north oriented oval-shaped gallery without side passages. Particularly in the middle part of the cave, there are large vertical dissolution holes ("bell-holes") in the ceiling of the cave (Fig. 10). In several places, these solutional hollows are over $2.5 \mathrm{~m}$ in diameter and one can be seen to extend upwards at least $5 \mathrm{~m}$ (Causer 1962).

A little north of the bell-holes is a group of three irregularly shaped pillars (Fig. 11), and, further on, an additional three columns (Fig. 12). At various places, massive stalactites hang from the ceiling (Fig. S5). A little further on, larger stalactitic flows are present on both walls, as well as a 2-m high lone stalagmite (Fig. S6). The back of the cave is well decorated with abundant stalactites and columns (Fig. 13) that prevent further progress, although cavities are visible behind them. 
Fig. 4 View from cave entrance over the church roof (note the crosses) towards Zeyi gorge. Photo Sofie Annys (2017)

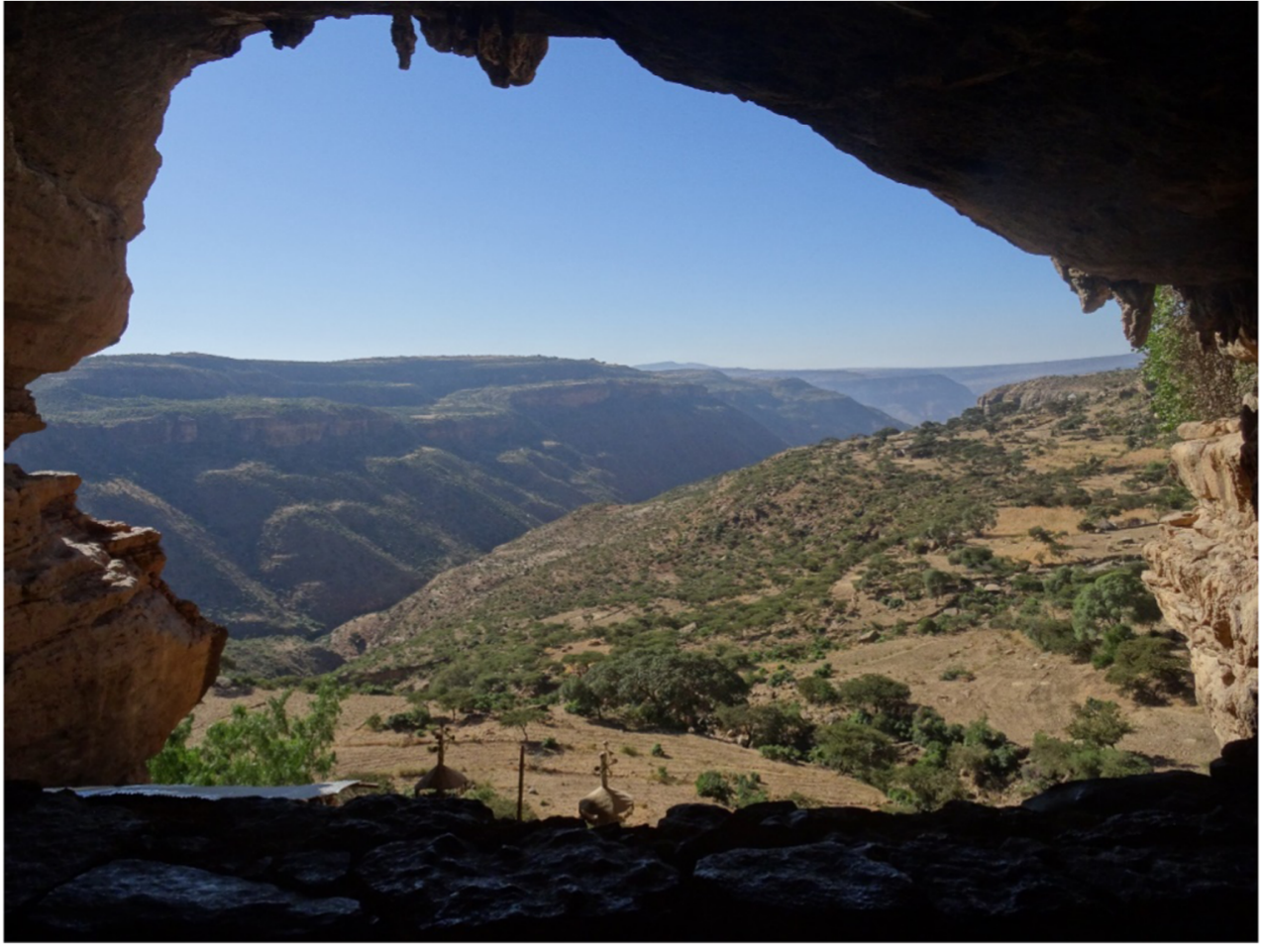

Very locally, in the middle part of the cave, water drips from the ceiling at slow discharge; it takes a week to fill a

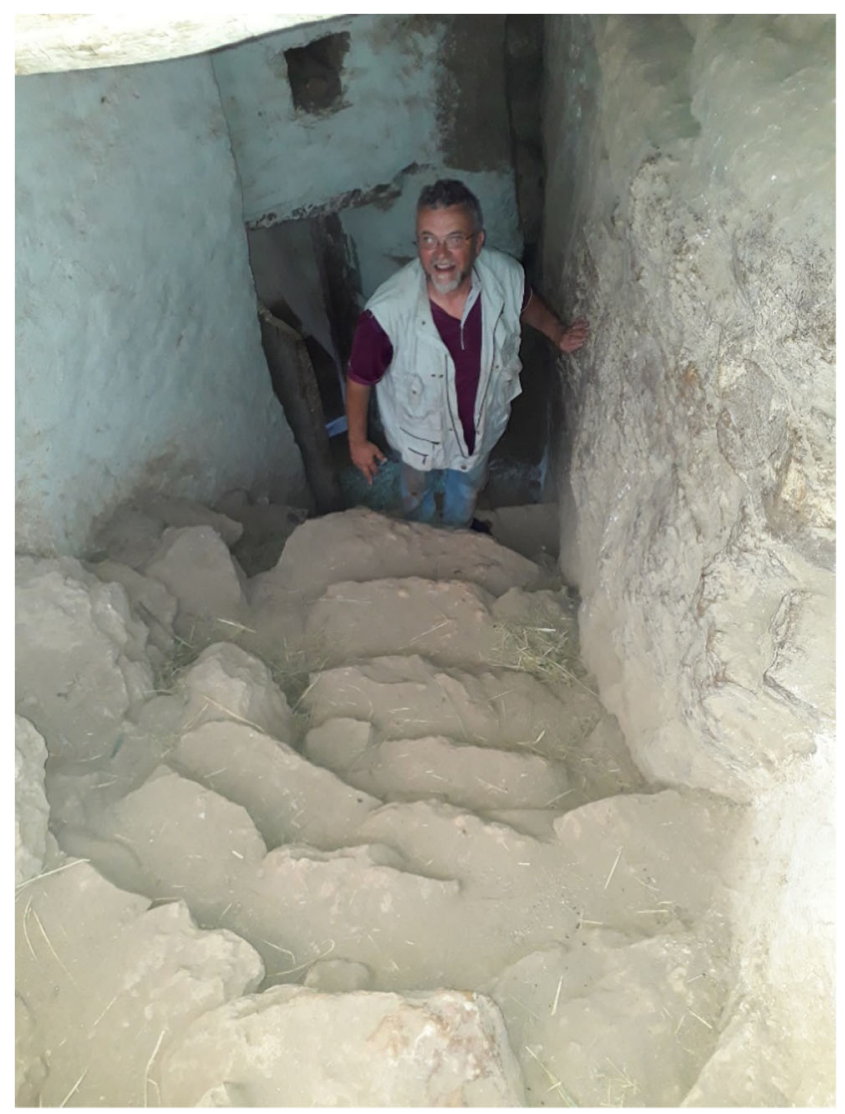

Fig. 5 The staircase towards Zeyi cave entrance. Photo Seifu Gebreselassie (2017) bucket, which corresponds approximately to a discharge of 0.121 per hour. A jar that was used in earlier times to collect the dripping water is standing in the cave and is covered by concretions that are cemented to it (Fig. 14).

Several metres of sediment are deposited on the floor of the cave, partly cemented by stalagmitic concretions. Especially on the eastern side of the cave, there are dozens of graves, excavated in the sediment that fills the bottom of the cave. Each grave is marked by two lozenge-shaped stones (Fig. 15). The cave was used as the village cemetery up to the 1980s.

\section{Estimated Age and Environmental Conditions of Cave Genesis}

The Zeyi cave (gallery) is obviously of solutional origin and has formed along a major north-south-oriented joint in the limestone. This is visible along the centre of the roof for the entire length of the cave, which is frequently hollowed out to a considerable size (Causer 1962). Such linear and regularised caves (Fig. 3) have typically been formed by flowing, rather than dripping, water. The sub-horizontal character of the gallery indicates an underground river with equilibrium profile. Currently, springs fed by limestone aquifers occur at various places in the valley bottoms of the wider area between Zeyi and Mekelle (Chernet and Eshete 1982). The cave is situated at about $2070 \mathrm{~m}$ a.s.l. whereas the local base level is at $1417 \mathrm{~m}$ a.s.l., i.e. the Giba River some $10 \mathrm{~km}$ south of the cave. 
Fig. 6 Top room of the Zeyi church buildings, which, at the back the entrance to the cave, hidden by a piece of cloth. Photo Sofie Annys (2017)

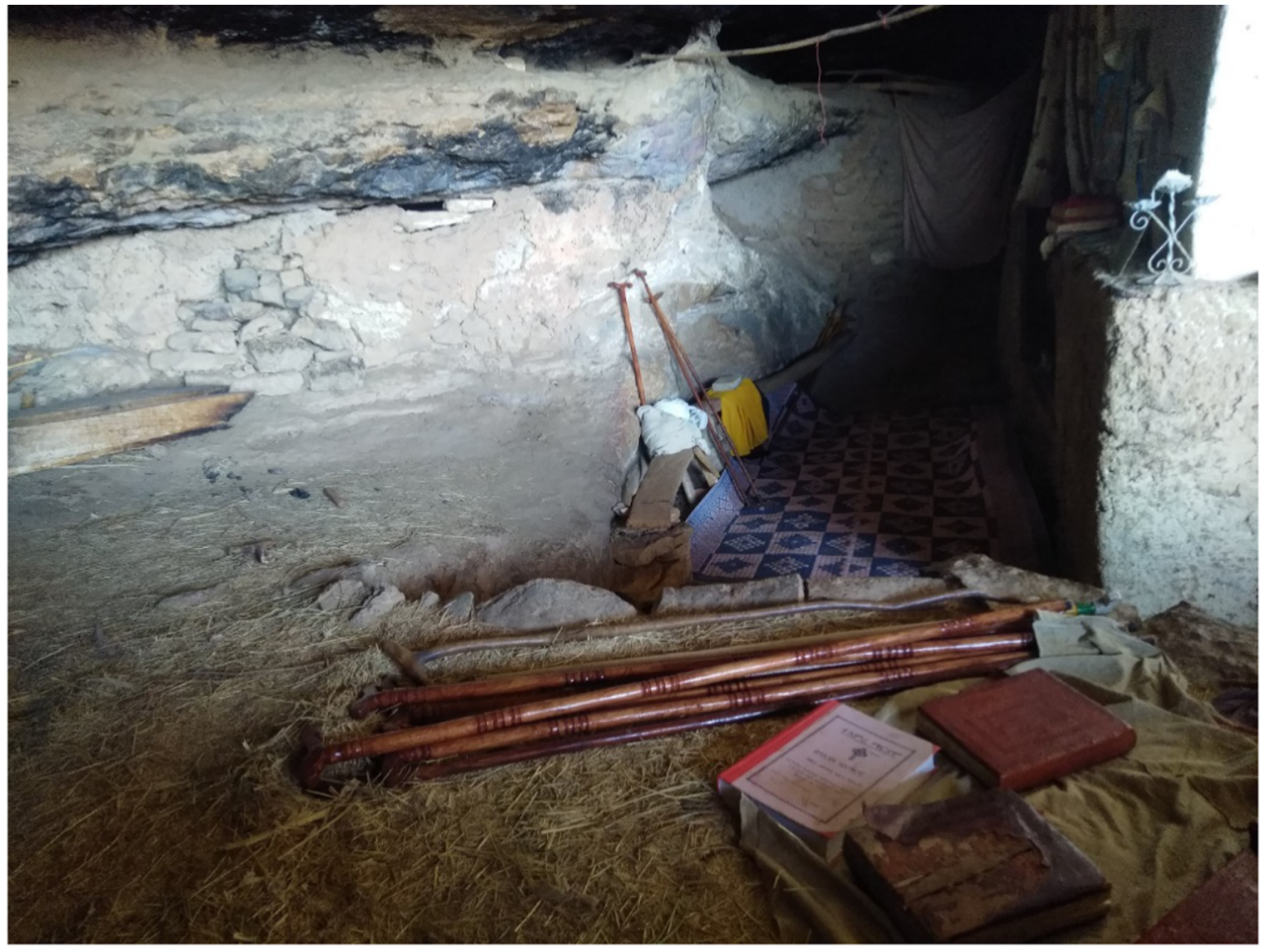

The May Hib'o cave (Gebreselassie and Lanckriet 2019), a 70-m long horizontal gallery some $9.6 \mathrm{~km}$ ESE of Zeyi (Fig. S7), is at an elevation of $1968 \mathrm{~m}$ a.s.l. Another major cave in the area, a $145-\mathrm{m}$ long horizontal gallery at $2230 \mathrm{~m}$ a.s.l., is located in a gorge flank opposite to a river confluence at Zeleqwa, $8.6 \mathrm{~km}$ NNE of Zeyi. There, towards the upper side of the cliff, an alignment of cavities is visible; these are the "windows" of a dissolution gallery that runs parallel to the river. The entrance to this so-called "Vase cave" is two "eyeholes", $8 \mathrm{~m}$ up a very difficult cliff to climb (Fig. S8). Access is possible for experienced rock climbers, though the villagers do not go there because they fear the place. Catlin et al. (1973)
Fig. 7 A narrow passage soon after the entrance of Zeyi cave (southernmost cross-section indicated in Fig. 3). Photo Jan Nyssen (2017)

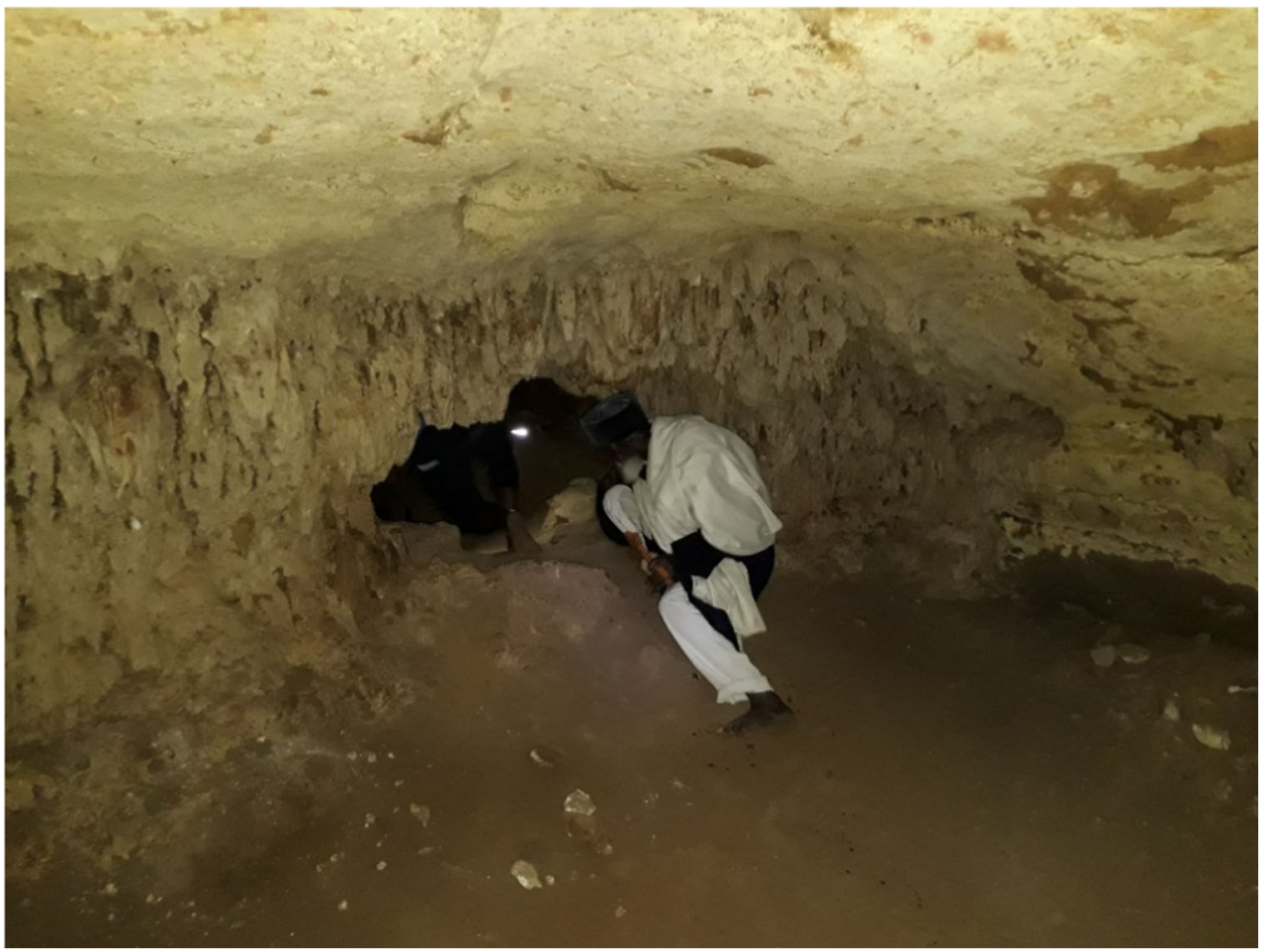




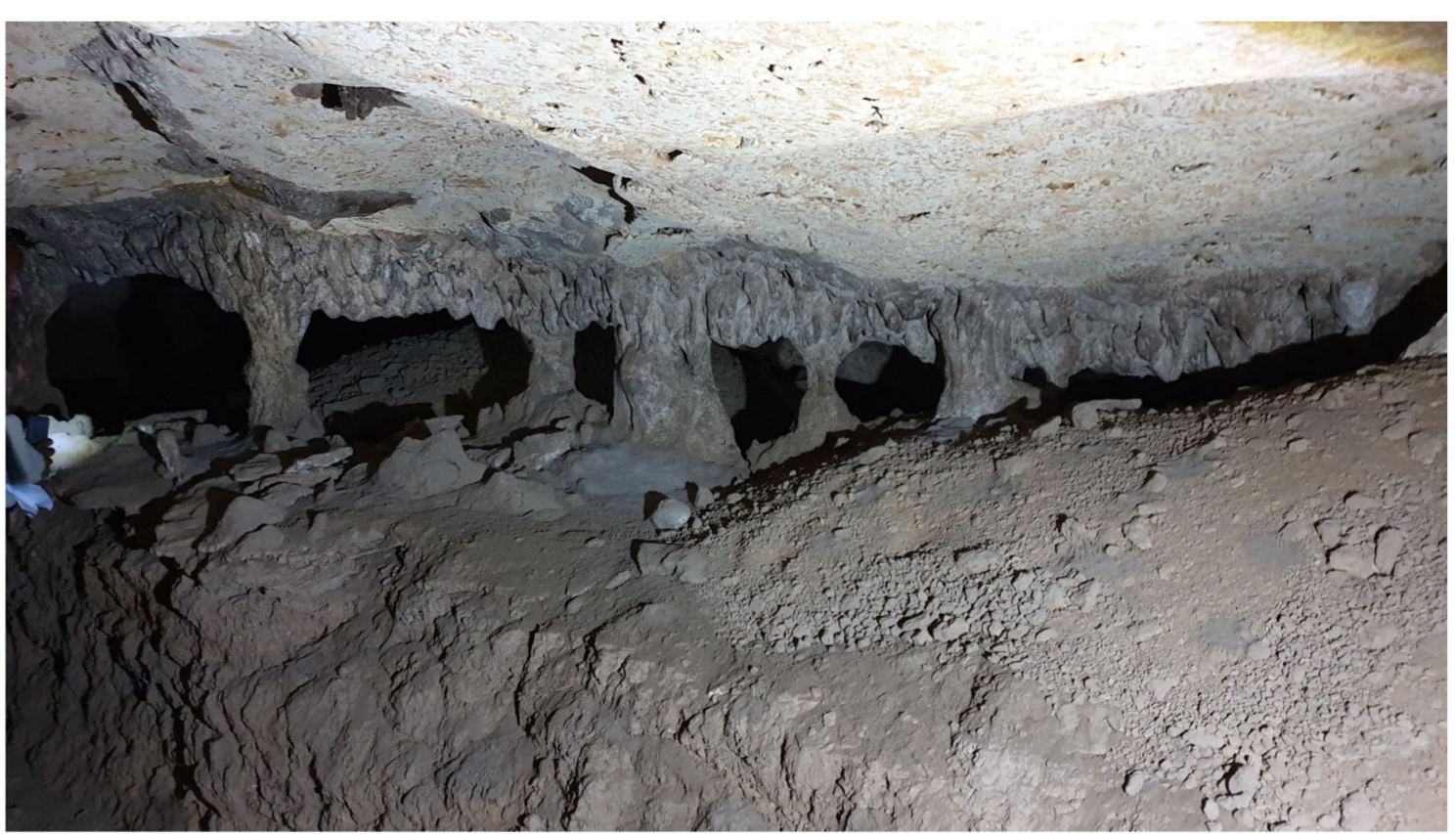

Fig. 8 Near the Zeyi cave entrance, the concretions form a floor covering the thick ancient sediment deposit. The floor and sediment have been partly excavated to facilitate entrance to the cave. Photo Jeroen Berlo (2019)

mentioned that the dusty cave floor is littered with jars of various sizes. Reportedly, the clay pots served to contain food

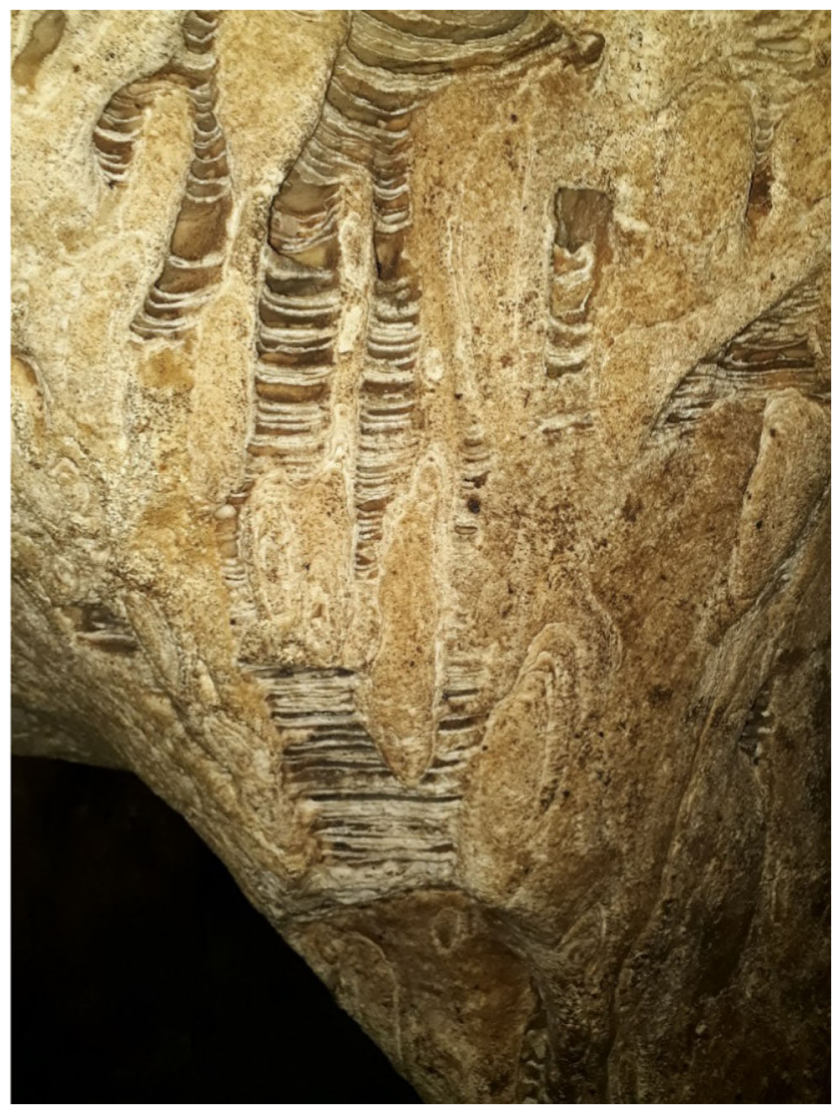

Fig. 9 Internal structure of damaged stalactite curtain near the entrance of Zeyi cave. Causer (1962) describes these curtains but makes no mention of the vandalism. Photo Jan Nyssen (2017) reserves for the villagers during "an inter-tribal war in about 1910". Catlin et al. (1973) further state that "the passage is formed in a fault and after some 30 metres closes down to a crawl which enters the fault continuation which is another 30 metres long. The cave also has a 50-metre long section north of the entrances".

At the bottom of the Antalo Limestone, where it overlays the Adigrat Sandstone, several high discharge resurgences drain the karst aquifer (Fig. 2). Secondary porosity and transmissivity are greater in the karstified limestone than in the underlying Adigrat sandstone (Tesfagiorgis et al. 2011; Chernet and Eshete 1982). At Rubaksa (1991 m a.s.1.), there is a large resurgence, sufficient to have an oasis in an otherwise dry limestone landscape (Fig. S9). Of special interest is the May Bilbil resurgence (1712 m a.s.1.), some $500 \mathrm{~m}$ upstream of the old bridge on the Giba River. Here, the resurgence is inside the Giba River bed and in the dry months, the spring water can be observed to surge through the baseflow of the river (Fig. S10) (Walraevens et al. 2019). May Bilbil and Rubaksa are in a similar stratigraphic position to Zeyi, at the contact of the Antalo Limestone with the underlying Adigrat Sandstone (Fig. 2), further upstream in valleys parallel to the Zeyi gorge. Those valleys are not yet incised deeply into the underlying stratigraphy, i.e. the resurgences are at the level of the current valley bottom. We may assume that the caves in Zeyi, Zeleqwa and May Hib'o were in a similar topographic position when water was running in the gallery that was then dominated by dissolution processes.

The formation of horizontal gallery caves is generally attributed to the circulation of groundwater during a relatively long period of stability in the water table and local river base 
Fig. 10 Upward view of a dissolution hole ("bell-hole") in the ceiling of Zeyi cave, about $1.5 \mathrm{~m}$ wide. Photo Jan Nyssen (2017)

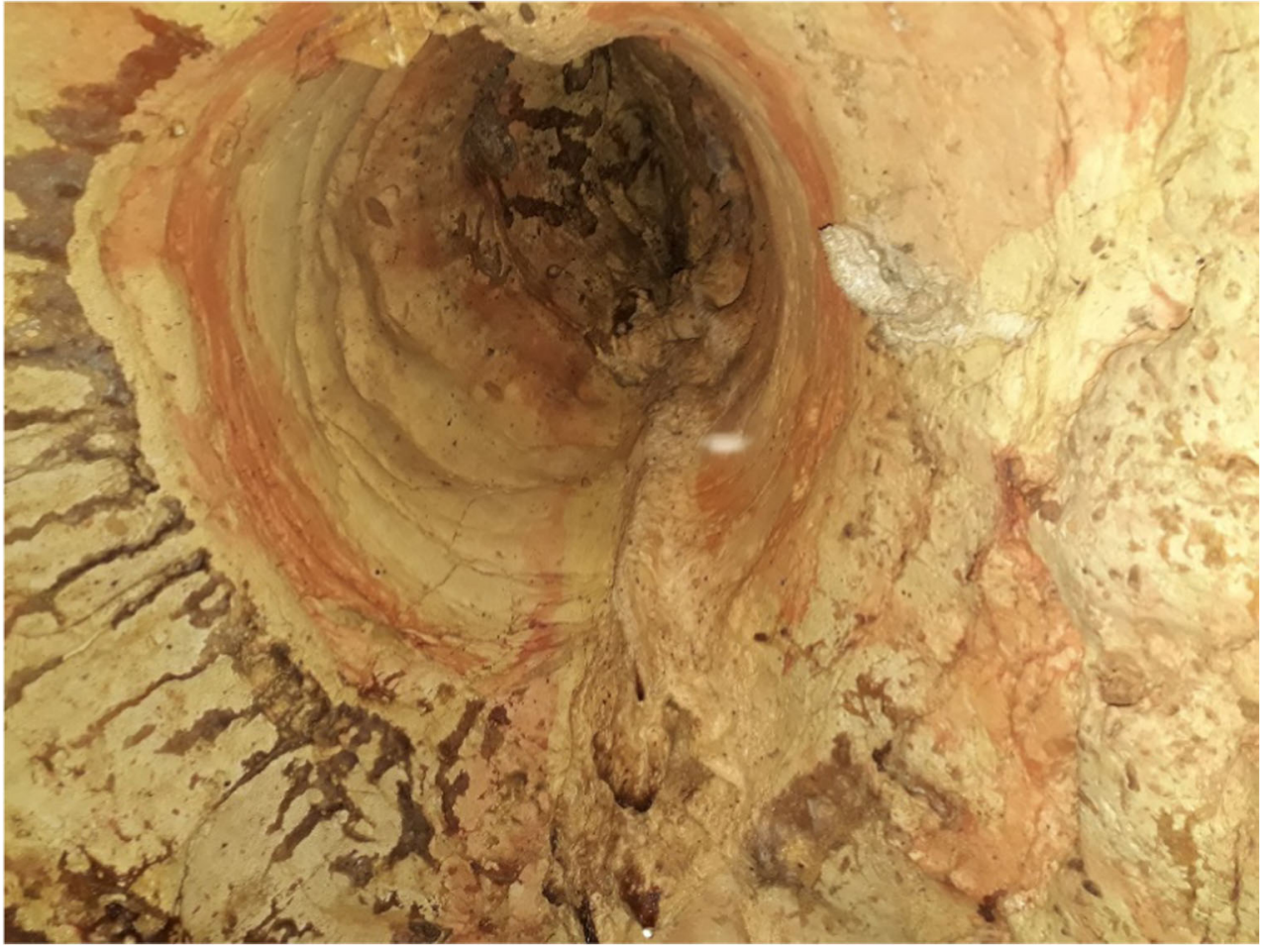

levels (Ek 1957; Ek 1961; Ford and Ewers 1978; Ortega et al. 2013; Palmer 1987). At local scales, there is a long-standing discussion as to whether caves develop in the vadose zone or at or below the regional groundwater table (Bretz 1942; Ford and Ewers 1978; Gabrovšek et al. 2014). What matters, for our purpose, is that active cave levels are in phase with the regional base levels. As rivers incise, different levels of caves tend to correspond to episodic stable levels during downcutting (Audra et al. 2006; Bakalowicz 2005; Ortega et al. 2013). In this way, known ages of caves allow the calculation of rates of river downcutting, as Piccini et al. (2003) did in the Apuan Alps in Italy. In a similar way, and in the absence of any dating of the Dogu'a Tembien caves, we may contrast their elevation above the current local base level with known average incision rates of the northern Ethiopian highlands to reconstruct the age of the caves. Besides the well-documented average uplift rate of $2000 \mathrm{~m}$ in $30 \mathrm{Ma}$ (Sembroni et al. 2016), Sepulchre et al. (2006) estimated the tectonic uplift of the Ethiopian highlands at $>1000 \mathrm{~m}$ in 6 million years. Hence, to a first approximation (Table 1), we calculated the minimum age of Zeyi cave to be 3.9 Ma, Zeleqwa 2.2 Ma and May Hib'o cave at least 2.9 Ma. Within this range, we have to consider that the basement rocks, located close to the partial base levels at Kemishana and May Lomi, are hard to incise. Hence, the caves are probably older than the calculated minimum ages of 2.2-3.9 Ma. In those periods, with landscapes that were about $1000 \mathrm{~m}$ less uplifted, the caves would have been at the level of the wider valley bottoms.

\section{Importance for Sub-Recent Landform Evolution}

The back of the cave is well decorated with abundant stalactites, and speleothems also cover the floor. The local narrative is that the cave extends well beyond that. As we had no speleological equipment, we did not proceed. The choked boulders at the end of the cave are evidence of cave collapse beyond this point. Most probably, in view of intervening East-West trending faults, the end of the cave scatters into smaller feeders.

A few hundred metres west of the Zeyi cave, there is a gorge which appears to be a collapsed cave with same northsouth orientation (Fig. 16; Fig. S11). The parallelism is another argument in favour of the solutional origin of the cave (Palmer 1991). Aerial photo observation shows several other depressions parallel to the Zeyi cave, which are interpreted as dry valleys over caves that have not yet collapsed. Hence, widening and collapse of caves must have been a major process in landform development in these limestone areas.

Further evidence for the contribution of cave collapse to landform development is the occurrence of stalagmites and stalactites under overhanging rocks on the side of the gorge and near Zeyi's cave entrance (Fig. 4). The side of the current gorge appears also to be the side of a previous cave. The observed concretions are notably different from the softer tufa stalagmites (Ford and Pedley 1996) observed on limestone cliff faces in the surrounding area. Unlike the small caves of 


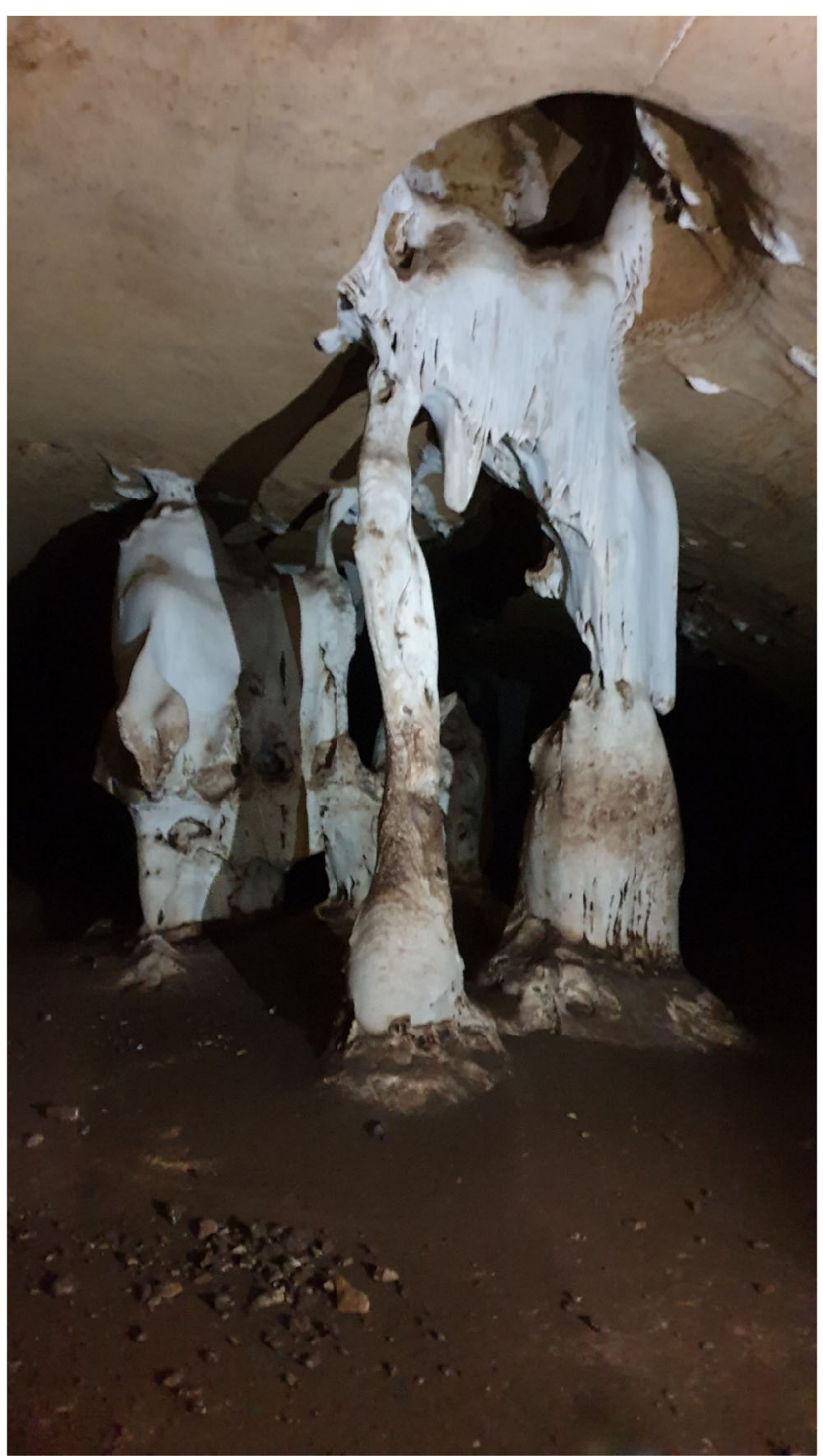

Fig. 11 The three pillars ("amdi" in Tigrinya), a bit further than half-way in Zeyi cave. Photo Jeroen Berlo (2019)

the Zeyi gorge, nearby tufa stalactites developed under openair conditions and do not show clear stalagmitic counterparts (Fig. S12).

\section{The Cave's Bat Colony}

Cave ecosystems seem separated from the outside environment, but are often highly linked with it because of the movement of bats (Hjort et al. 2015). At Zeyi, a large colony of bats roosts around the middle of the cave at the left (western) side. As part of a survey study focusing on cave bats in Tigray, nine individual bats belonging to three syntopically roosting species (Fig. 17), Hipposideros megalotis, Hipposideros tephrus and Rhinolophus blasii, were captured in the Zeyi cave. The individuals were mist netted (nylon monofilament $0.08 \mathrm{~mm}$,
$6 \mathrm{~m} \times 2.5 \mathrm{~m}$ ) at the cave entrance on February 24, 2017. Species types were genetically confirmed.

Hipposideros megalotis (Ethiopian large-eared roundleaf bat), six individuals, all males (average forearm length $35 \mathrm{~mm}$, range 34-36 mm; average weight $4.2 \mathrm{~g}$, range 3$7 \mathrm{~g}$ ). H. megalotis is a rare, small orange bat with long ears, distributed in East Africa and the Arabian Peninsula (Monadjem and Shapiro 2017a). It is a rare species in Ethiopia (this is the third record for the country - pers. comm. Petr Benda, National Museum \& Charles University, Prague). H. megalotis occurs in dry savanna, subtropical or tropical dry shrubland, caves and hot deserts. Further study is needed to better understand the feeding habit, distribution, ecology and threats to this enigmatic species.

Hipposideros tephrus, two individuals, male (forearm length $46 \mathrm{~mm}$, weight $6 \mathrm{~g}$ ) and female (forearm length $45 \mathrm{~mm}$, weight $6 \mathrm{~g}$ ). Confirmed to occur in Morocco, Senegal and Yemen, the species has presumably a wide distribution in North and West Africa and the Arabian Peninsula, and between these areas in arid ecosystems, dry open and coastal forests (Monadjem and Shapiro 2017b). H. tephrus is a colonial leaf-nosed species commonly occurring in caves in Tigray (unpubl. data).

Rhinolophus blasii (Blasius's horseshoe bat), one female individual (forearm length $46 \mathrm{~mm}$, weight $7 \mathrm{~g}$ ). $R$. blasii has a patchy Palaearctic and Afrotropical (parts of North, East and Southern Africa) distribution (Jacobs et al. 2016; Taylor 2016). Unlike the other two bats, this species is not common in caves and occurs in groups of no more than three or four individuals (Jacobs et al. 2016). This was the only individual of the species we have sampled during our assessment of Tigray's caves. $R$. blasii is known to feed on lepidopterans that can be pest of agriculture and household (Cooper 2009).

Zeyi was the only cave where three syntopically roosting bat species were encountered, out of the six caves assessed in Tigray so far. The other cave bat roosts were composed of one gregarious species. The exact distribution of the three bat species in Ethiopia as well as their role in insect pest control is still under investigation. Like other caves, Zeyi is an example of why geodiversity is important to biodiversity: besides the bats, probably highly distinctive biota occurs, adapted to life in darkness and, in our case, relatively constant warm temperature (Culver and Pipan 2009). Furthermore, the geographic isolation among caves can also generate fauna and flora that is endemic to a limited area (Hjort et al. 2015).

\section{Scope for Archaeological and Palaeo-Environmental Research}

The graves in the sediments of the Zeyi cave might indicate that the place is an ancient burial site. Cave burial is a very ancient tradition in the Ethiopian highlands. Finneran (2012) 

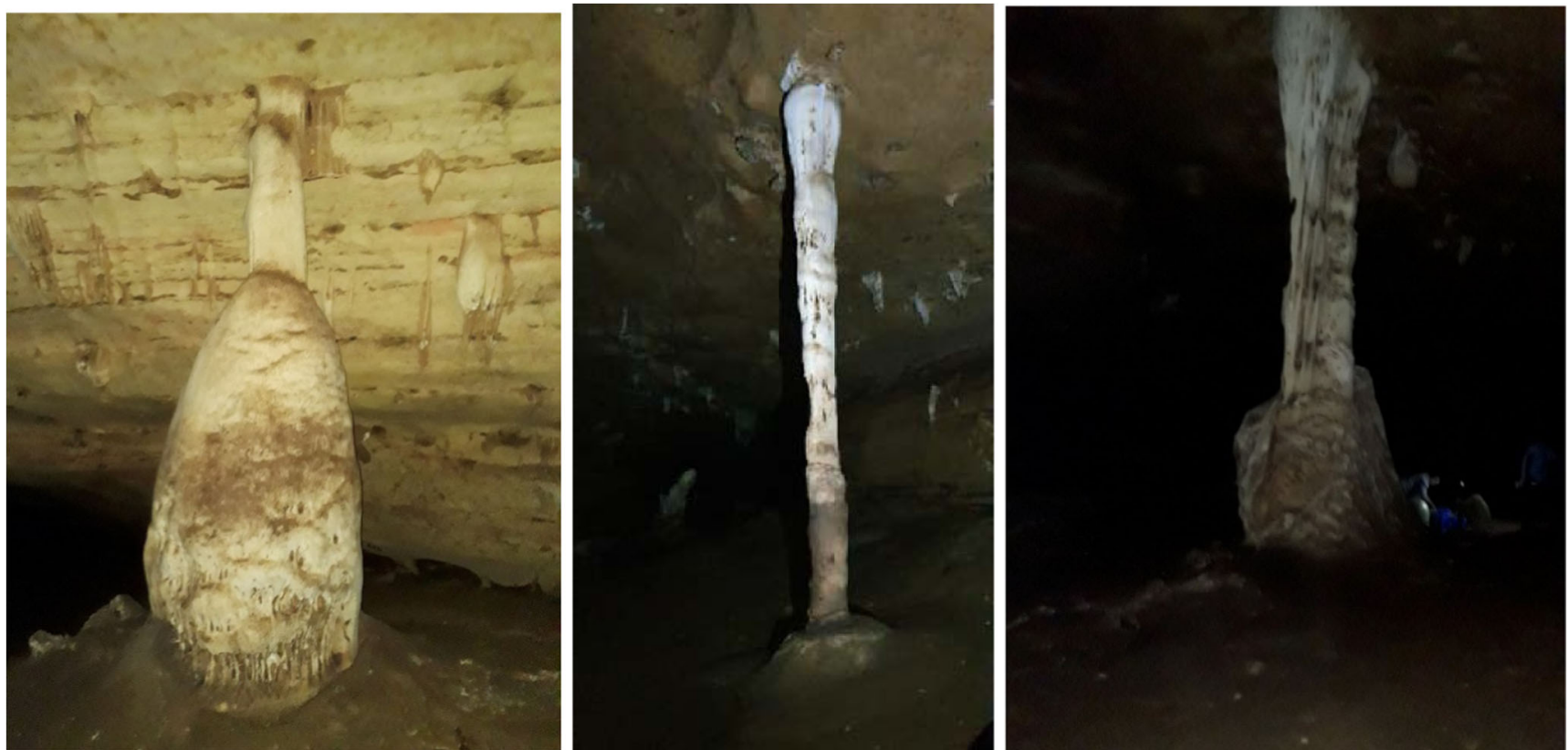

Fig. 12 Three individual columns in Zeyi cave: (left) with remarkably broader speleothems (stalagmitic floor) around its foot (photo Jan Nyssen 2017), (middle) the highest (photo Jeroen Berlo 2019) and (right) the best

shows that caves were burial places in the Aksumite (fourth c. BCE-ninth c. CE) and Zagwe (11th-thirteenth c.) periods and considers the use of caves for churches and cemeteries as a Christianisation of an earlier sacred spot. He refers to ContiRossini (1905) for attachment to caves by the older Agaw ethnic group. Underground tunnels, caves or caverns in rocks developed column - current collection of holy water with plastic jars at the back (photo Jan Nyssen, 2017)

play a crucial role in diverse religious and other ancient traditions of the Tigrayan highlanders (Pankhurst and Aspen 2005). While today this is seen as a Christian tradition, the continuity with much early rock burials from pre-Christian times shows that it is deeply enrooted in a local spiritual tradition pre-dating Christianity. For instance, Llorente et al.

Fig. 13 The back of Zeyi cave is well decorated with abundant stalactites and concretions also cover the floor. The priest and local people claim that the cave extends well beyond. Photo Jan Nyssen (2017)

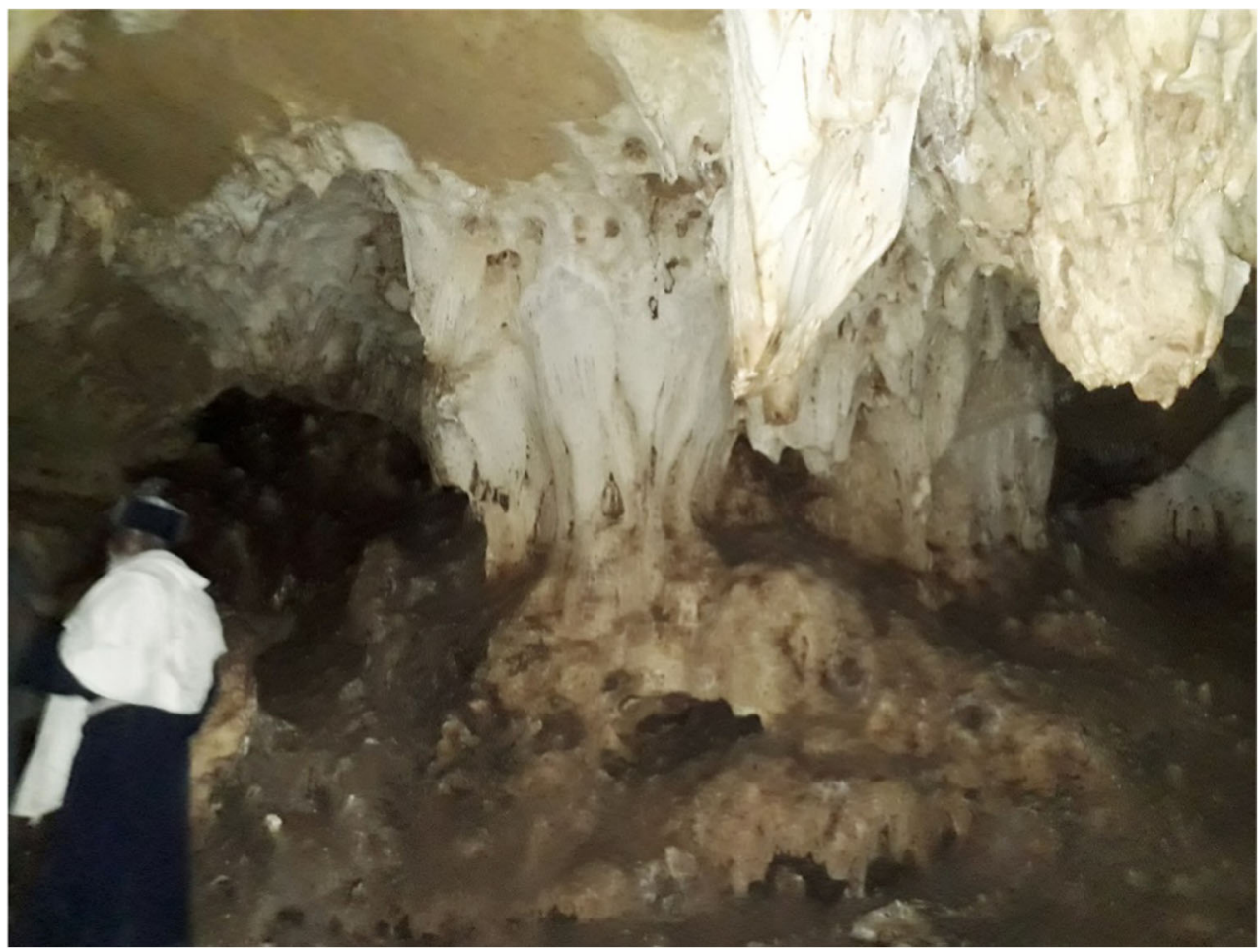




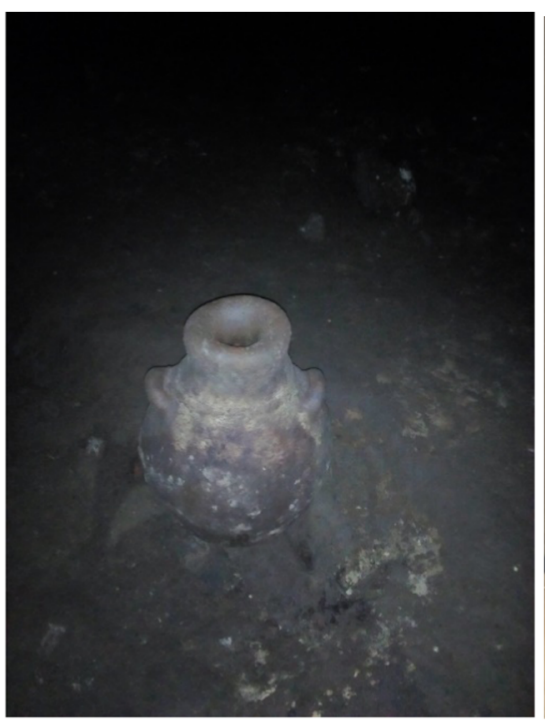

Fig. 14 Jar that was placed in Zeyi cave in 1958 (according to the local priest) to collect water dropping from the ceiling, to be used as holy water in religious ceremonies (photo Seifu Gebreselassie 2017), with (right)

(2015) excavated the approx. 4500-year-old burial site of the "Mota man" in a small cave in southern Ethiopia, and Dombrowski (1970) studied the burial site of two infants (1100-1400 CE) in a cave in Natchabiet (east of Lake Tana). Hence, is it assumed that old human remains, possibly accompanied by artefacts, can be found at Zeyi, what gives scope for archaeological research.

Analysis of the cave sediment may reveal important information about the environmental history of the region. Although part of the sediment has been reworked due to one side of the cave having been used as a cemetery, the larger part detail of its top - concretions are well-developed inside the jar also (photo Jan Nyssen 2017)

appears intact, certainly where it is covered by calcite concretions (Fig. 8). The history that is archived in the sediment would cover the Pleistocene, in line with the findings in the "Estimated Age and Environmental Conditions of Cave Genesis" section. The sediment thickness is the greatest at the back of the cave and near the entrance. The fine texture suggests that it has been deposited by slow accumulation, representing long periods of accumulation, most probably with hiatuses.

Similarly, the speleothems in the caves provide unique and datable archives of environmental conditions during

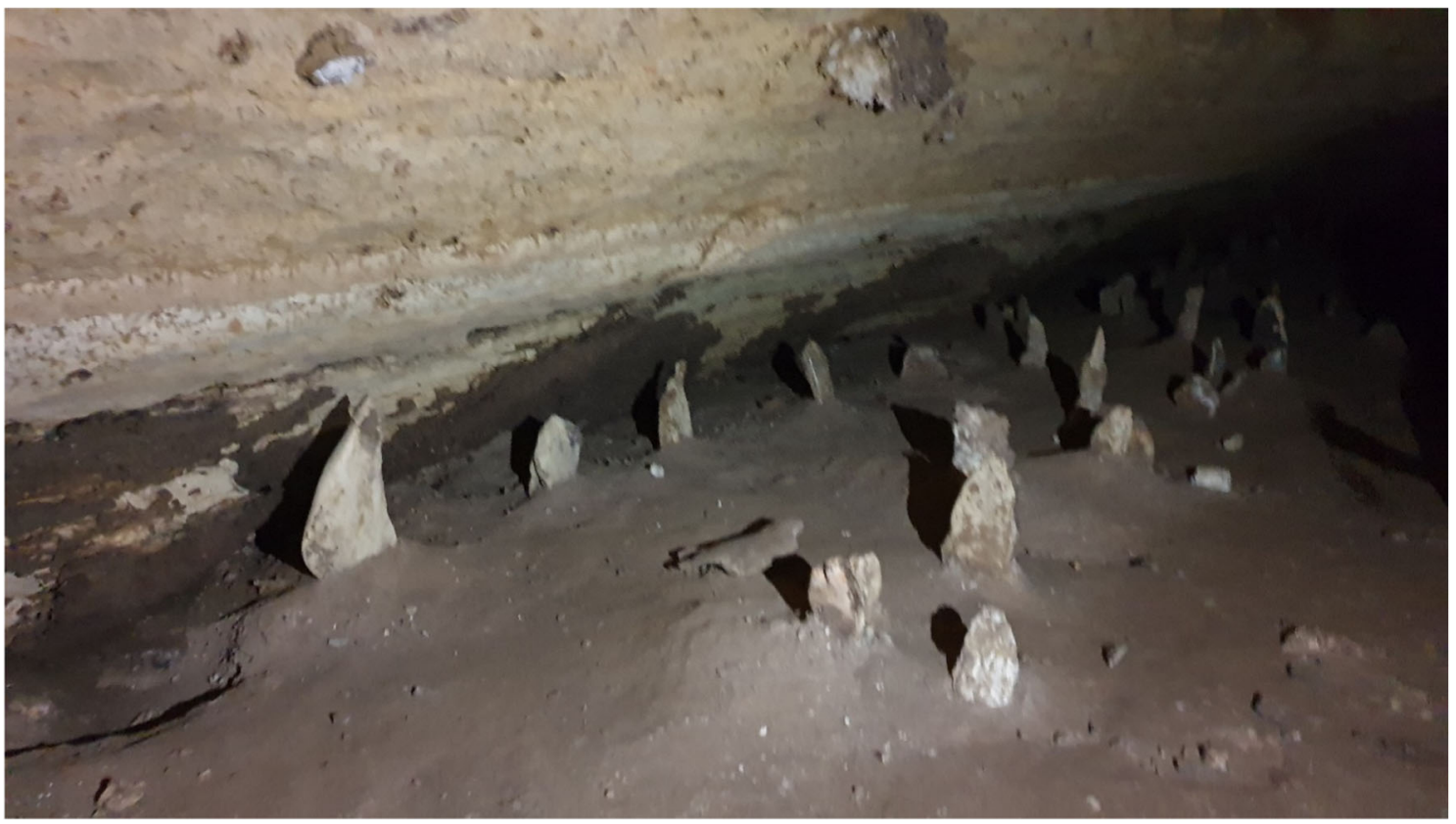

Fig. 15 Partial view of the underground graveyard in the Zeyi cave. Photo Jeroen Berlo (2019) 
Table 1 Elevations of Dogu'a Tembien's caves and regional base levels, and calculation of minimum and maximum ages of the karstic galleries

\begin{tabular}{|c|c|c|c|c|c|c|c|}
\hline \multicolumn{3}{|c|}{ Cave or spring altitude } & \multicolumn{2}{|l|}{ Present partial base level } & \multirow{2}{*}{$\begin{array}{l}\Delta z \\
\text { (m) }\end{array}$} & \multicolumn{2}{|c|}{ Age $(\mathrm{Ma})^{\mathrm{a}}$} \\
\hline & & m a.s.l. & & $\mathrm{m}$ a.s.l. & & Min & Max \\
\hline Zeyi & $\mathrm{C}$ & 2070 & Giba R. at Kemishana & 1417 & 653 & 3.9 & 9.7 \\
\hline Zeleqwa & $\mathrm{C}$ & 2230 & May Lomi & 1863 & 367 & 2.2 & 5.5 \\
\hline May Hib'o & $\mathrm{C}$ & 1968 & Junction of Giba R. and Inda Sillase R. & 1476 & 492 & 2.9 & 7.3 \\
\hline Rubaksa & $\mathrm{S}$ & 1991 & Rubaksa & 1991 & 0 & & \\
\hline May Bilbil & $\mathrm{S}$ & 1712 & May Bilbil & 1712 & 0 & & \\
\hline
\end{tabular}

${ }^{\text {a }}$ Plio-Pleistocene maximal incision rate of $167 \mathrm{~m} / \mathrm{Ma}$ to calculate the minimum age, and minimal rate of $67 \mathrm{~m} / \mathrm{Ma}$ to calculate the maximum age (Sembroni et al. 2016; Sepulchre et al. 2006). Real age probably is at the lower side of this range, in line with delayed incision induced by basement rocks located just underneath the local base levels precipitation periods (Asrat 2001). Uranium series dating of speleothems (Spötl and Boch 2019) is emerging in cave studies in Ethiopia (Asrat et al. 2018; Asrat et al. 2007; Baker et al. 2010).

\section{Potential and Drawbacks for Geotourism to the Cave}

Ethiopia has a lot to offer to geotourists (Asrat et al. 2008; Mauerhofer et al. 2018; Williams 2016), and Zeyi could become one of the geotouristic destinations, given its unique ABC combination (Brilha 2016; Hagos et al. 2019; Reynard 2004): "A" for abiotic, with the presence of the unique cave, the speleothems and the panoramic views of cliffs and gorges; "B" for biotic with the cave's bat colonies as well as a remnant church forest on the foot of the cliff with a large number of vervet monkeys (Chlorocebus pygerythrus) and "C" for cultural with the unique church buildings, the underground graveyard and the Zeyi village with its traditional agroforestry system and recently improved land management, which allows the resilient inhabitants to change the challenges of their environment into opportunities. The suitability of the terrain for trekking (Online Supplement, Section S2) is another ace.

Major drawback for geotourism is however the gender bias, as women are allowed to visit the church but not the cave. Reasons invoked are possible impurity of menstruations and the narrative that after women entered the cave (for instance for protection during the civil war of the 1980s), there was noise like a lion's roaming in the cave for the three following years. In the context of the patriarchal society in Ethiopia, "many of the socialisation agents including family, school, the church, and the community perpetuate the unfair gender relationship prevalent in the society" (Cherinet and Mulugeta

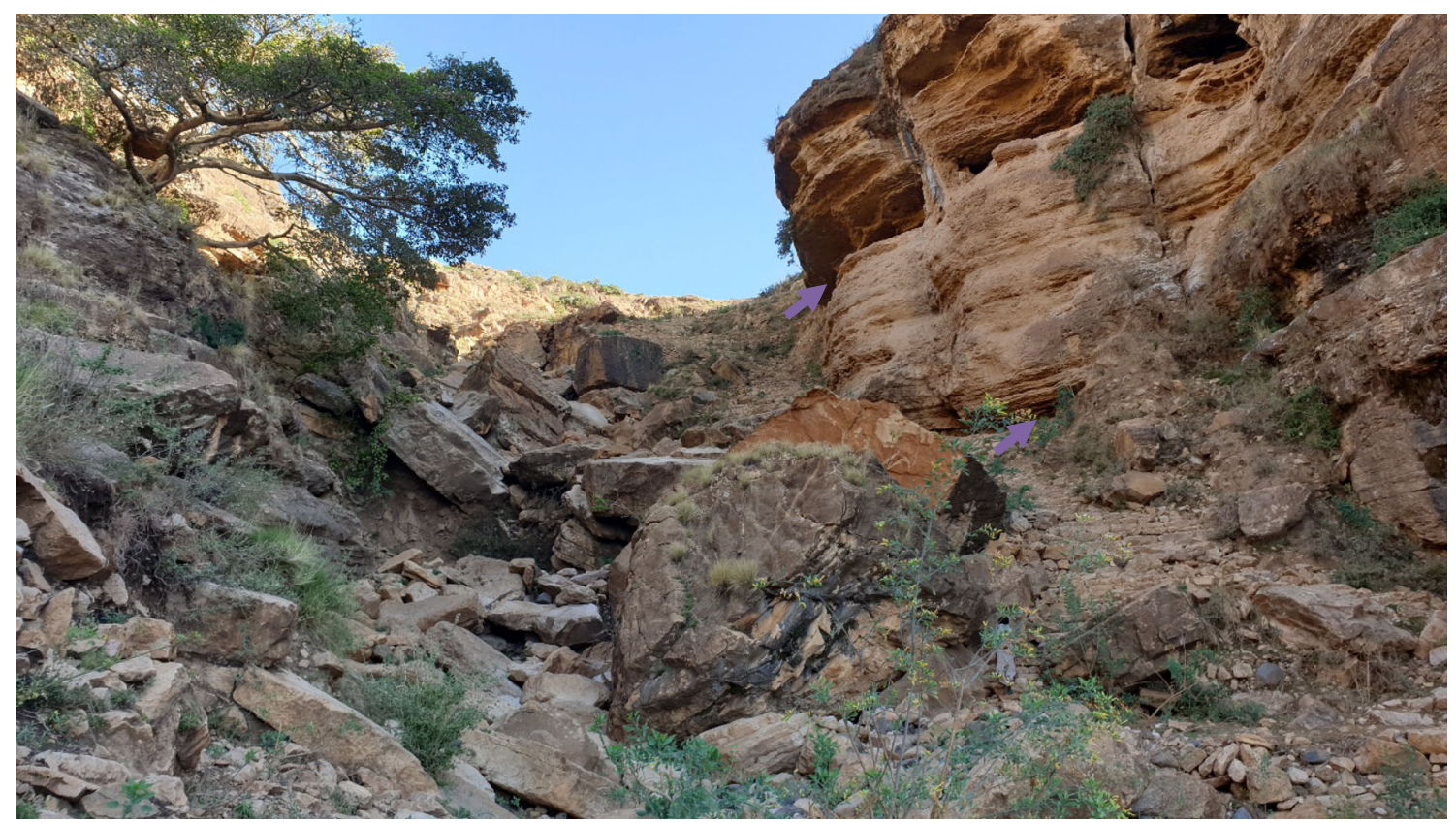

Fig. 16 Debris of a collapsed cave roof litter the bottom of a small gorge (Fig. S11) parallel to the Zeyi cave. Arrows indicate cavities holding stalactites and stalagmites on the flanks of the previous cave. Photo Jeroen Berlo (2019) 

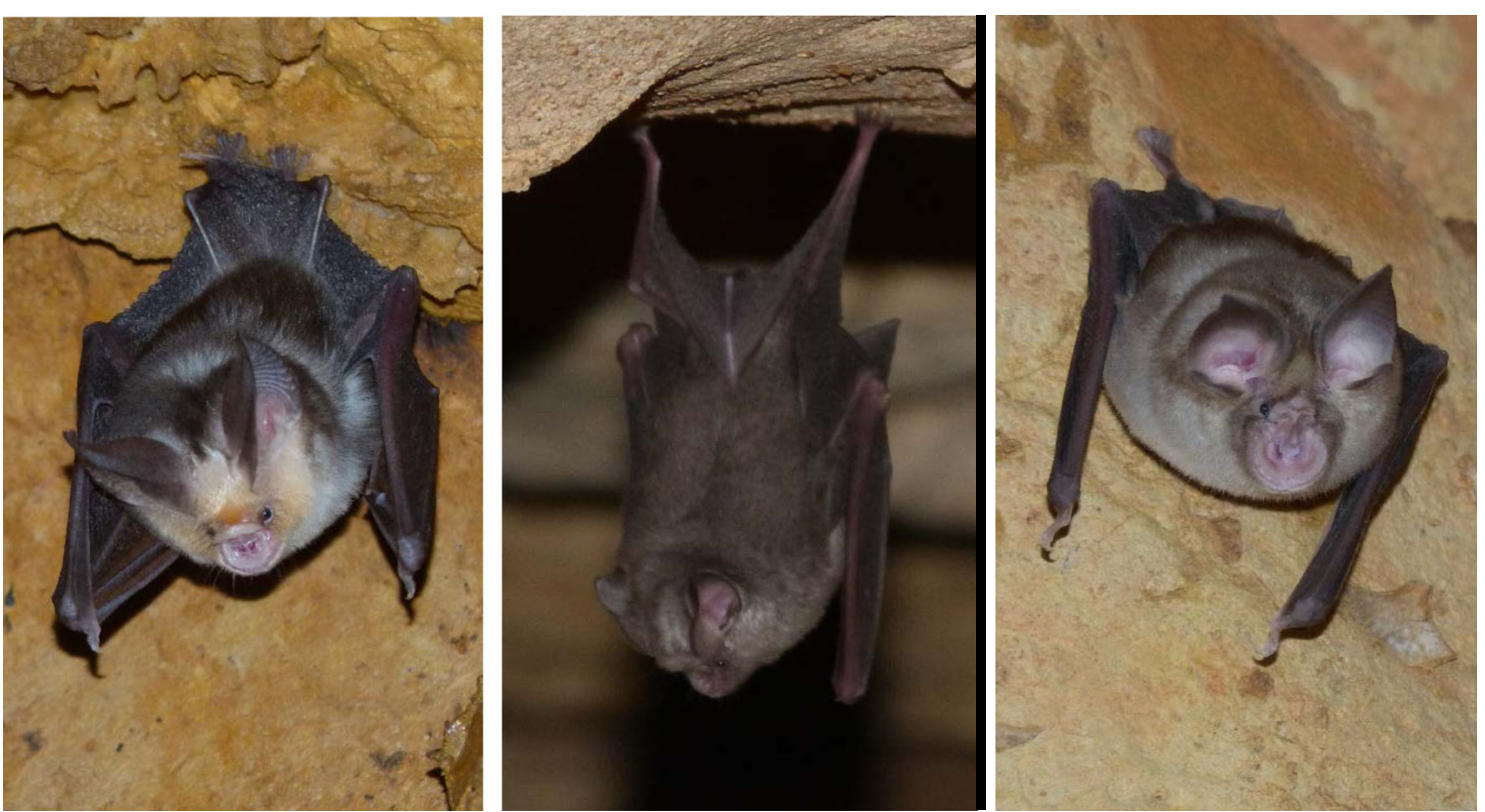

Fig. 17 Specimen of the three bat species photographed in Zeyi cave, showing their faces and ears very clearly since these body parts are used as distinctive features for taxonomic identification. From left to right
Hipposideros megalotis, H. tephrus and Rhinolophus blasii. Photos Ara Monadjem (18 September 2019)
2002). As in a great number of human societies, "men's sureness of their sex roles is tied up with their right, or ability, to practise some activity that women are not allowed to practise" (Figes 1986). Many monasteries in Ethiopia, for instance, do not allow female visitors, what generates incomprehension in tourist groups and leads to certain touristic places to be avoided by tourist groups (Getnet 2018). In this case, the monastery itself is accessible, and the interdiction for women to access the cave pertains more to social construct than to religion. If this can be changed, and income generated from tourism, the Zeyi cave will become a geotourism hotspot.

\section{Conclusions}

The Zeyi cave is not only the seventh largest cave in Ethiopia, but has unique features such as its magnificent setting high above the current valley bottom in combination with its cultural heritage. There is a colony of vervet monkeys in the remnant forest at the foot of the cliff in which the cave is found, and colonies of three different bat species are present in the cave.

Considering the incision of the surrounding valleys and known downcutting rates, we calculated that the cave is at least 3.9 million years old. Hence, the metres of fine sediment on the bottom of the cave are assumed to hold an undisturbed environmental record of the Quaternary. The stalagmitic floor that is deposited over it in several locations, as well as the speleothems, gives scope for U/Th dating. Of interest for archaeologists is the fact that the cave has been used as a burial site until recently, and possibly since ancient times.

Considering size and setting of the cave, there is much room for sustainable geotourism. One bottleneck, however, is the gender-based discrimination that is traditionally enforced on the visitors. Provided that vandalism and unintentional damage can be avoided and a good balance found between cave research, community-based geotourism, geoconservation and biodiversity conservation (Gordon 2018; Hjort et al. 2015; Kiernan 2013; Świerkosz et al. 2017), the Zeyi cave has strong credentials to become a geotouristic site in Ethiopia.

Acknowledgements The authors thank Kiros Mamun for introduction to the Zeyi community, villagers and priests for hosting and guiding them in the cave, as well as accompanying visitors to the cave, including Zbelo Tesfamariam, Jeroen Berlo, Gebrekidan Mesfin, Berhane Gebre, Yemane Gebremichael Teklehaimanot and Kahsu Kiros. Abba Teklehaimanot Gebreslassie, the monk in charge of the Zeyi church and cave, shared his knowledge with us. Key informants from cave sites in the wider surroundings of Zeyi are gratefully acknowledged, as well as local authorities.

\section{References}

Arkin Y, Beyth M, Dow D, Levitte D, Haile T, Hailu T (1971) Geological map of Mekele sheet area ND 37-11, Tigre province, 1:250.000. Imperial Ethiopian Government, Ministry of Mines, Geological survey, Addis Ababa 
Asrat A (2001) The limestone caves of Tigray: their potential for speleothem palaeoclimate studies. In: Nyssen J, Asrat A, Dramis F, Umer M (eds) Excursion Guide, IAG Regional Conference "Geomorphology for Human Adaptation to Changing Tropical Environments", post-conference excursion to the Northern Ethiopian Highlands, February 16-22, 2011. Addis Ababa, pp $141-142$

Asrat A (2002) The rock-hewn churches of Tigrai, Northern Ethiopia: a geological perspective. Geoarchaeology 17:649-663

Asrat A (2015) Geology, geomorphology, geodiversity and geoconservation of the Sof Omar Cave System, southeastern Ethiopia. J Afr Earth Sci 108:47-63

Asrat A, Baker A, Umer M, Leng MJ, Van Calsteren P, Smith C (2007) A high-resolution multi-proxy stalagmite record from Mechara, Southeastern Ethiopia: palaeohydrological implications for speleothem palaeoclimate reconstruction. J Quat Sci 22:53-63

Asrat A, Demissie M, Mogessie A (2008) Geotourism in Ethiopia: archaeological and ancient cities, religious and cultural centres: Yeha, Azum, Wukru, and Lalibela. Shama Books, Addis Ababa

Asrat A, Baker A, Leng M, Hellstrom J, Mariethoz G, Boomer I, Yu D, Jex C, Gunn J (2018) Paleoclimate change in Ethiopia around the last interglacial derived from annually-resolved stalagmite evidence. Quaternary Science Reviews 202:197-210.

Audra P et al (2006) Cave genesis in the Alps between the Miocene and today: a review. Z Geomorphol 50:153-176

Bakalowicz M (2005) Karst groundwater: a challenge for new resources. Hydrogeol J 13:148-160

Baker A, Asrat A, Fairchild I, Leng M, Thomas L, Widmann M, Jex C, Dong B, van Calsteren P, Bryant C (2010) Decadal-scale rainfall variability in Ethiopia recorded in an annually laminated, Holocene-age, stalagmite. Holocene 20:827-836

Berakhi O, Brancaccio L, Calderoni G, Coltorti M, Dramis F, Umer MM (1998) The Mai Maikden sedimentary sequence: a reference point for the environmental evolution of the Highlands of Northern Ethiopia. Geomorphology 23:127-138. https://doi.org/10.1016/ s0169-555x(97)00108-6

Beyth M (1972) Paleozoic-Mesozoic sedimentary basin of Makalle outlier. Am Assoc Pet Geol Bull 56:2426-2439

Bosellini A, Russo A, Fantozzi PL, Getaneh A, Solomon T (1997) The Mesozoic succession of the Mekele outlier (Tigre Province, Ethiopia). Memorie di Scienze Geologiche 49:95-116

Bretz JH (1942) Vadose and phreatic features of limestone caverns. J Geol $50: 675-811$

Brilha J (2016) Inventory and quantitative assessment of geosites and geodiversity sites: a review. Geoheritage 8:119-134

Bussert R, Nyssen J (2019) Rock-hewn sandstone churches and manmade caves in and around Dogu'a Tembien. In: Nyssen J, Jacob M, Frankl A (eds) Geo-trekking in Ethiopia's tropical mountains, GeoGuide. Springer, Cham (CH), pp 121-137

Catlin D, Largen M, Monod T, Morton W (1973) The caves of Ethiopia. Transactions of the Cave Research Group of Great Britain 15:107168

Causer D (1962) A cave in Ethiopia. Wessex Cave Club J 7:91-94

Cherinet H, Mulugeta E (2002) Country gender profile Ethiopia. Swedish International Development Cooperation Agency (SIDA), Addis Ababa

Chernet T, Eshete G (1982) Hydrogeology of the Mekele area. Ministry of Mines and Energy, Addis Ababa

Coltorti M, Dramis F, Ollier C (2007) Planation surfaces in northern Ethiopia. Geomorphology 89:287-296

Conti-Rossini C (1905) Appunti sulla lingua Awiyà del Denghelà. Giornale della Società Asiatica Italiana 18: 116-118

Cooper C (2009) Rhinolophus blasii, Animal Diversity Web. Accessed November 27, 2018 at https://animaldiversity.org/accounts/ Rhinolophus_blasii/
Culver DC, Pipan T (2009) The biology of caves and other subterranean habitats. Oxford University Press, Oxford

Dombrowski J (1970) Preliminary report on excavations in Lalibela and Natchabiet caves, Begemeder. Annales d'Ethiopie 8:21-29

Dramis F, Fubelli G (2019) Limestone, karst and tufa dams in the western part of the Mekelle outlier. In: Nyssen J, Jacob M, Frankl A (eds) Geo-trekking in Ethiopia's tropical mountains, the Dogu'a Tembien district, Springer GeoGuides, vol 1. Springer Nature, Heidelberg, pp 107-119. https://doi.org/10.1007/978-3-030-04955-3 7

Ek C (1957) Les terrasses de l'Ourthe et de l'Amblève inférieures. Ann Soc Geol Belg 80:333-353

Ek C (1961) Conduits souterrains en relation avec les terrasses fluviales. Ann Soc Geol Belg 84:313-340

Figes E (1986) A man's god. In: Figes E, Patriarchal attitudes. Springer, pp 35-65

Finneran N (2012) Hermits, saints, and snakes: the archaeology of the early Ethiopian monastery in wider context. Int J Afr Hist Stud 45: 247-271

Ford DC, Ewers RO (1978) The development of limestone cave systems in the dimensions of length and depth. Can J Earth Sci 15:17831798

Ford T, Pedley H (1996) A review of tufa and travertine deposits of the world. Earth Sci Rev 41:117-175

Gabrovšek F, Häuselmann P, Audra P (2014) 'Looping caves' versus 'water table caves': the role of base-level changes and recharge variations in cave development. Geomorphology 204:683-691

Gebreselassie S, Lanckriet S (2019) Local myths in relation to the natural environment of Dogu'a Tembien. In: Nyssen J, Jacob M, Frankl A (eds) Geo-trekking in Ethiopia's tropical mountains, the Dogu'a Tembien district, Springer GeoGuides, vol 1. Springer Nature, Heidelberg, pp 519-528. https://doi.org/10.1007/978-3-03004955-3_35

Gebreyohannes T, De Smedt F, Hagos M, Gebresilassie S, Amare K, Kabeto K, Hussein A, Nyssen J, Bauer H, Moeyersons J, Deckers J, Haile M, Taha N (2010) Large-scale geological mapping of the Geba basin, northern Ethiopia. vol 9. Tigray Livelihood Papers. VLIR-Mekelle University IUC Programme, Mekelle

Getnet Z (2018) Assessing potentials and challenges of Haiq Estifanos Communal Monastery for cultural heritage tourism development. Afr J Hist Cult 10:15-24

Gordon J (2018) Geoheritage, geotourism and the cultural landscape: enhancing the visitor experience and promoting geoconservation. Geosciences 8:136

Hagos M, Nyssen J, Amare K, Poesen J (2019) Geosites, geoheritage, human-environment interactions, and sustainable geotourism in Dogu'a Tembien. In: Nyssen J, Jacob M, Frankl A (eds) Geotrekking in Ethiopia's tropical mountains, the Dogu'a Tembien district, Springer GeoGuides, vol 1. Springer Nature, Heidelberg, pp 3 27. https://doi.org/10.1007/978-3-030-04955-3 1

Hamilton-Smith E (2007) Karst and world heritage status. Acta carsologica 36: 291-302

Hjort J, Gordon JE, Gray M, Hunter ML Jr (2015) Why geodiversity matters in valuing nature's stage. Conserv Biol 29:630-639

Jacobs D, Cohen L, Richards LR, Monadjem A, Schoeman C, MacEwan K, Sethusa T, Taylor P (2016) A conservation assessment of Rhinolophus blasii. In: Child MF, Roxburgh L, Do Linh SE, Raimondo D, Davies MHT (eds) The Red List of Mammals of South Africa, Swaziland and Lesotho. South African National Biodiversity Institute and Endangered Wildlife Trust, Midrand

Kiernan K (2013) The nature conservation, geotourism and poverty reduction nexus in developing countries: a case study from the Lao PDR. Geoheritage 5:207-225

Llorente MG et al (2015) Ancient Ethiopian genome reveals extensive Eurasian admixture in eastern Africa. Science 350:820-822

Mauerhofer L, Reynard E, Asrat A, Hurni H (2018) Contribution of a geomorphosite inventory to the geoheritage knowledge in 
developing countries: the case of the Simien Mountains National Park, Ethiopia. Geoheritage: 10(4):559-574

Moeyersons J, Nyssen J, Poesen J, Deckers J, Haile M (2006) Age and backfill/overfill stratigraphy of two tufa dams, Tigray highlands, Ethiopia: evidence for Late Pleistocene and Holocene wet conditions. Palaeogeogr Palaeoclimatol Palaeoecol 230:165-181. https://doi.org/10.1016/j.palaeo.2005.07.013

Monadjem A, Shapiro J (2017a) Hipposideros megalotis. In: The IUCN Red List of Threatened Species 2017. p e.T85646524A85646528

Monadjem A, Shapiro J (2017b) Hipposideros tephrus. In: The IUCN Red List of Threatened Species 2017. p e.T85646524A85646528

Nyssen J (2019) Description of trekking routes in Dogu'a Tembien. In: Nyssen J, Jacob M, Frankl A (eds) Geo-trekking in Ethiopia's tropical mountains, the Dogu'a Tembien district, Springer GeoGuides, vol 2. SpringerNature, Cham $(\mathrm{CH})$, pp 557-675. https://doi.org/10. 1007/978-3-030-04955-3_38

Ortega A, Benito-Calvo A, Pérez-González A, Martín-Merino M, PérezMartínez R, Parés J, Aramburu A, Arsuaga J, Bermúdez de Castro J, Carbonell E (2013) Evolution of multilevel caves in the Sierra de Atapuerca (Burgos, Spain) and its relation to human occupation. Geomorphology 196:122-137

Palmer AN (1987) Cave levels and their interpretation. NSS Bull 49:50 66

Palmer AN (1991) Origin and morphology of limestone caves. Geol Soc Am Bull 103:1-21

Pankhurst R, Aspen H (2005) Grave culture in Christian regions. In: Uhlig S (ed) Encyclopaedia Aethiopica, vol 2. Harrassowitz Wiesbaden, Wiesbaden, pp 873-875

Piccini L, Drysdale R, Heijnis H (2003) Karst morphology and cave sediments as indicators of the uplift history in the Alpi Apuane (Tuscany, Italy). Quat Int 101:219-227

Pierson B (2009) The limestone hills of the Kinta Valley: a part of Malaysia's geological heritage worth preserving. First Break 27: 97-100

Plant R, Buxton D (1970) Rock-hewn churches of the Tigre province Ethiopia. Observer 13:159-267

Reynard E (2004) Geosite. In: Goudie AS (ed) Encyclopedia of geomorphology, vol 1. Routledge, London, p 440

Russo A, Fantozzi P, Tadesse S (1999) Geological map of Mekele outlier (western sheet), 1:100,000. Cooperazione Italiana, Roma
Sembroni A, Faccenna C, Becker TW, Molin P, Abebe B (2016) Longterm, deep-mantle support of the Ethiopia-Yemen Plateau. Tectonics 35:469-488

Sembroni A, Molin P, Dramis F, Abebe B (2017) Geology of the Tekeze River basin (Northern Ethiopia). J Maps 13:621-631

Sembroni A, Molin P, Dramis F (2019) Regional geology of the Dogu'a Tembien Massif. In: Nyssen J, Jacob M, Frankl A (eds) Geotrekking in Ethiopia's tropical mountains, the Dogu'a Tembien district, Springer GeoGuides, vol 1. Springer Nature, Heidelberg, pp 29-43. https://doi.org/10.1007/978-3-030-04955-3 2

Sepulchre P, Ramstein G, Fluteau F, Schuster M, Tiercelin J-J, Brunet M (2006) Tectonic uplift and Eastern Africa aridification. Science 313: 1419-1423

Spate A, Baker A 2018 Karst values of Kosciuszko National Park: a review of values and of recent research. Proceedings of the Linnean Society of New South Wales 140:253-264

Spötl C, Boch R (2019) Uranium series dating of speleothems. In: White W, Culver D, Pipan T, eds, Encyclopedia of caves. Elsevier, pp 1096-1102

Świerkosz K, Koźma J, Reczyńska K, Halama M (2017) Muskau Arch Geopark in Poland (Central Europe) - is it possible to integrate geoconservation and geoeducation into biodiversity conservation? Geoheritage 9:59-69

Taylor P (2016) Rhinolophus blasii. In: The IUCN Red List of Threatened Species 2016. p e.T19515A21972073

Tesfagiorgis K, Gebreyohannes T, De Smedt F, Moeyersons J, Hagos M, Nyssen J, Deckers J (2011) Evaluation of groundwater resources in the Geba basin, Ethiopia. Bull Eng Geol Environ 70:461-466

Walraevens K, Camp M, Vandecasteele I, Clymans W, Moeyersons J, Frankl A, Guyassa E, Zenebe A, Poesen J, Descheemaeker K, Nyssen J (2019) Hydrological context of water scarcity and storage on the mountain ridges in Dogu'a Tembien. In: Nyssen J, Jacob M, Frankl A (eds) Geo-trekking in Ethiopia's tropical mountains, the Dogu'a Tembien district, vol 1. Springer Nature, Heidelberg, pp 197-213. https://doi.org/10.1007/978-3-030-04955-3_13

Watson J, Hamilton Smith E, Gillieson D, Kiernan K (1997) Guidelines for cave and karst protection. Prepared by the WCPA Working Group on Cave and Karst Protection. International Union for the Conservation of Nature, Gland

Williams FM (2016) Understanding Ethiopia - geology and scenery. Springer, Cham 